\title{
MACROINVERTEBRATE INSTREAM FLOW STUDIES AFTER 20 YEARS: A ROLE IN STREAM MANAGEMENT AND RESTORATION
}

\author{
JAMES A. GORE ${ }^{\mathrm{a}, *}$, JAMES B. LAYZER ${ }^{\mathrm{b}}$ AND JIM MEAD

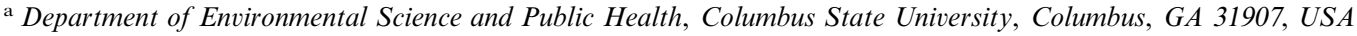 \\ ${ }^{\mathrm{b}}$ US Geological Survey, Tennessee Cooperative Fishery Research Unit, Tennessee Tech University, PO Box 5114, Cookeville, \\ TN 38505, USA \\ ${ }^{\mathrm{c}}$ Instream Flow Unit, Division of Water Resources, North Carolina Department of Environment and Natural Resources, \\ 1611 Mail Service Center, Raleigh, NC 27699-1611, USA
}

\begin{abstract}
Over the past two decades of refinement and application of instream flow evaluations, we have examined the hydraulic habitat of aquatic macroinvertebrates in a variety of conditions, along with the role of these macroinvertebrates in sustaining ecosystem integrity. Instream flow analyses assume that predictable changes in channel flow characteristics can, in turn, be used to predict the change in the density or distribution of lotic species or, more appropriately, the availability of useable habitat for those species. Five major hydraulic conditions most affect the distribution and ecological success of lotic biota: suspended load, bedload movement, and water column effects, such as turbulence, velocity profile, and substratum interactions (near-bed hydraulics). The interactions of these hydraulic conditions upon the morphology and behavior of the individual organisms govern the distribution of aquatic biota. Historically, management decisions employing the Physical Habitat Simulation (PHABSIM) have focused upon prediction of available habitat for life stages of target fish species. Regulatory agencies have rarely included evaluation of benthos for flow reservations. Although 'taxonomic discomfort' may be cited for the reluctant use or creation of benthic criteria, we suggest that a basic misunderstanding of the links between benthic macroinvertebrate and the fish communities is still a problem. This is derived from the lack of a perceived 'value' that can be assigned to macroinvertebrate species. With the exception of endangered mussel species (for which PHABSIM analysis is probably inappropriate), this is understandable. However, it appears that there is a greater ability to predict macroinvertebrate distribution (that is, a response to the change in habitat quality or location) and diversity without complex population models. Also, habitat suitability criteria for water quality indicator taxa (Ephemeroptera, Plecoptera, and Trichoptera; the so-called 'EPTs') may also provide additional management options to stream regulators. The greatest application for macroinvertebrate criteria will be in low-order streams where a more immediate link to fish communities can be established. We present an example from Queens Creek, in North Carolina, USA, in which monthly allocations required to preserve the integrity of the benthic macroinvertebrate community were significantly higher than for the target benthic fish species, Cottus bairdi. In the months when both Cottus and community diversity of macroinvertebrates were the 'bottleneck' life stages, preservation of only fish species could result in an additional $5-25 \%$ loss in macroinvertebrate habitat. We suggest that, as there becomes an increased emphasis on maintaining macroinvertebrates as monitors of stream health, there will be a concurrent emphasis on incorporating hydraulic habitat conditions as a part of bioassessment. Copyright (C) 2001 John Wiley \& Sons, Ltd.
\end{abstract}

KEY WORDS: IFIM; instream flow analysis; macroinvertebrate community diversity; mussels; PHABSIM

\section{INTRODUCTION}

Among the body of techniques used to evaluate minimum flows and to make flow recommendations for stream managers, the Instream Flow Incremental Methodology (IFIM) (Stalnaker et al., 1995), along with the software associated with the technique (most notably, the Physical Habitat Simulation, PHABSIM) (Milhous et al., 1984), has received the greatest attention from regulatory agencies around the world. In its original form, the ease of calibration of the one-dimensional flow model combined with relatively

* Correspondence to: Department of Environmental Science and Public Health, Columbus State University, Columbus, GA 31907, USA. E-mail: gore_james@colstate.edu

Copyright (C) 2001 John Wiley \& Sons, Ltd. 
simple habitat characteristics of target fish has made its application appealing in a variety of water resource management conflicts. Being originally designed to address problems related to minimum or optimal flows for various life stages of salmonid species in rivers dominated by snowmelt hydrographs in the western United States, in general, other state agencies continued to apply the technique by addressing the flow requirements to maintain critical game species. Only recently has it been demonstrated that the single target-species approach is probably not appropriate to many river and stream ecosystems. For example, in the southeastern United States, warmwater rivers host among the most species-rich temperate freshwater fish assemblages in the world (Freeman, 1998). This high richness presents a number of challenges to choose appropriate targets for management and the development and evaluation of habitat-use guilds have often replaced the single-species approach (Freeman, 1998; Leonard and Orth, 1988). As an alternative, some regulatory agencies have chosen to evaluate several individual species, each being representative of specific habitat types. Quite often, a species of darter (Etheostoma or Percina, family Percidae) or sculpin [bullhead] (Cottus, family Cottidae) is evaluated to represent fast-riffle species. The assumption has been made that the maintenance of habitat for these riffle-feeders will certainly support the food base, those benthic macroinvertebrates species dwelling in the riffles. This assumption relieves regulatory agencies and system modelers of the task of creating habitat suitability criteria for a myriad of benthic species, not to mention the concurrent difficulties in collecting and identifying the various species dwelling in that lotic system. Over the past two decades of refinement and application of instream flow evaluations, we have examined the hydraulic habitat of aquatic macroinvertebrates in a variety of conditions, along with the role of these macroinvertebrates in sustaining ecosystem integrity. We suggest that evaluation of benthic fish species may not be an appropriate surrogate for aquatic macroinvertebrates. Macroinvertebrates are, effectively, food for fish. But, it remains very difficult to demonstrate that invertebrate density can influence fish growth and populations dynamics. Few studies (e.g. Mundie, 1974) have attempted to directly link macroinvertebrate and fish production. However, with the critical role of aquatic invertebrates in the processing of nutrients and organic energy in any running water ecosystem (see, for example, Cummins, 1996) and the increased emphasis on multiple-species conservation and management in all ecosystems (Pearson, 2000; Redak, 2000), it is becoming increasingly necessary to evaluate maintenance of macroinvertebrate communities in both regulated flow conflicts and in planning the restoration or preservation of critical habitat areas. Our examination of the appropriate use of macroinvertebrate habitat criteria in regulated stream management and restoration is the subject of this paper.

Although the instream flow requirements for benthic macroinvertebrates received equal attention during the development of IFIM, perceived difficulties in collection (large sample size), taxonomic identification, habitat suitability curve generation, as well as inability to assign 'benefit' to the maintenance of benthic communities have led most regulatory agencies to conclude that enough flow for target fish species (and their individual life stages) was also sufficient for benthic species, as a source of food. Even with increased emphasis on more comprehensive evaluation of lotic biota, there is a certain amount of controversy regarding the amount of effort required and/or the need for accuracy in the development of habitat models. When benthic macroinvertebrate evaluations are required, it is often left to the best judgement of the stream manager to decide the appropriate taxonomic level for management target. However, unless the target macroinvertebrate is listed as an endangered or threatened species under the Endangered Species Act of 1973, the larger question asked by the applicant to the regulatory agency is, 'Are aquatic macroinvertebrate studies necessary?'

\section{NEAR-SUBSTRATE CONDITIONS}

The interaction of depth and velocity with the substrate profile is of critical importance to the range of potential microhabitats available to benthic macroinvertebrates (Statzner et al., 1988). When these simple characteristics are combined with such criteria as kinematic viscosity, density of the water, and power slope, such conditions as Froude number, shear velocity, thickness of the viscous sublayer and shear stress 
have been shown to be able to predict the distribution and, in some cases, the density of macroinvertebrates in a stream reach (Gore, 1996, provides a summary of these studies). Although studies of flow in flumes have indicated the existence of a non-moving boundary layer (up to $2 \mathrm{~mm}$ in thickness) (Nowell and Jumars, 1984) and lotic scientists have indicated that morphological and behavioral adaptations are directed towards existence within this boundary layer (Hynes, 1970), recent investigations have determined that very few benthic macroinvertebrates are sufficiently streamlined to take advantage of this boundary layer (Statzner, 1987). Indeed, a true boundary layer condition rarely exists under natural flow conditions because of the complex profile of the substrate. Thus, aquatic organisms are restricted to those combinations of velocity, depth, and substrate that allow morphological and/or behavioral resistance to flow to be exceeded by energetic gains.

Any hydrological change that leads to increases in shear velocities or shear stress or reduction in the thickness of the viscous sublayer will reduce the availability of adequate microhabitats to some species while increasing habitat availability for others. Since the abundance of various species will change with changes in physical habitat location and accessibility, in turn, community functioning and food-web dynamics may be changed to the extent that some species will be locally eliminated from the community.

Near-substratum conditions are further changed with changes in substrate composition or distribution since increased hydraulic roughness increases the rate of sediment deposition (Harvey and Watson, 1986), in turn, altering community composition through elimination of some species (increased predation success) (Brusven and Rose, 1981) or elimination of some or all primary production (Brusven and Prather, 1974).

\section{THE 'VALUE' OF MACROINVERTEBRATES}

Aquatic macroinvertebrates occupy a unique compartment within the structure of lotic ecosystem. As processors of organic material (either allochthonous or authochthonous), the invertebrates serve as the critical link to the fish community as food for game and forage fish. Gore $(1977,1978)$ showed that many macroinvertebrate species have a narrow range of tolerances to changes in discharge. Being less mobile than fish, most macroinvertebrates lack the ability to return to a previously inhabited area. Thus, under fluctuating flows, patches of slowly recolonizing habitat support a different community structure and very different densities of benthic species (Gore and Milner, 1990). IFIM predictions have demonstrated that a small-percentage loss of fish habitat may not necessarily result in a comparable loss of macroinvertebrate habitat, whose losses may be two- or three-fold greater (Gore, 1989). However, it is has been rare over the past two decades that macroinvertebrate habitat considerations have been made. This decline in the food base and/or community structure has the potential of leading to further degradation of the target fish species for management, as well as less efficient energy processing throughout the ecosystem. It is important, then, that prediction of changes in macroinvertebrate habitat be considered in conjunction with analysis of instream flow requirements for target fish species. This requires the assessment of the distribution of benthic species, construction of models of habitat suitability, and application of the models to appropriate hydrologic/habitat management models of that regulated stream or river. One of the most common assessment and management tools has been IFIM, and its associated software, PHABSIM (Stalnaker et al., 1995; Bovee et al., 1998).

\section{MACROINVERTEBRATE HABITAT SUITABILITY CURVES}

In addition to hydrological and hydraulic calibration data, PHABSIM requires information on the suitability of (or preference for) velocity, depth, and substrate criteria of target species for management. Although evaluation of macroinvertebrates is not common in the United States, previously published ('catalog') criteria have been used in limited application (see, for example, Bovee, 1985). However, on-site development of habitat suitability information yields the most accurate predictions (Bovee, 1986; Gore, 1987). This is especially important for benthic macroinvertebrates since community composition varies 
from system to system. Niche characteristics will change as a result of changes in predation, competitive interactions, habitat location, and availability, as well as food resources. Habitat criteria, as mimics of niche dimensions (Hutchinson, 1959), will likely change with changes in species composition or composition of functional groups in the community in any given lotic ecosystem.

Gore and Judy (1981) have developed a technique for describing macroinvertebrate suitability curves for PHABSIM application. This curve development relies upon standard techniques for benthic macroinvertebrate sampling. Using a circular bottom sampler (Waters and Knapp, 1961), Surber sampler (Surber, 1937), or other area-defining samplers, measurements of depth, mean water column velocity, and substrate characteristics are recorded for a series of samples (we suggest between 25 and 50 samples) taken at random along transects across a 'typical' stream reach. In most cases, riffle samples are used since these organisms are the most likely to be impacted by decreased flows (usually the management alternative being examined). Stratification of the sampling scheme, based upon proportions of substrate type, appears to reduce the number of samples required to produce accurate suitability curves (Statzner et al., 1988).

Suitability curves are derived from a fit of a third- or fourth-order polynomial to a plot of cumulative mean number of individuals of a taxon per sample as a function of an arbitrarily chosen increment of each physical habitat parameter. As an alternative, cumulative mean sample diversity per habitat parameter can be plotted. Any of these plots results in a sigmoid curve-fit. The polynomial should be fit only over the range of physical habitat values measured.

A primary derivative of the fit polynomial (when normalized to a maximum value of 1.0; as greatest suitability) will provide a suitability curve applicable to the habitat simulation routines contained within PHABSIM. In the case of a plot of diversity values, this curve indicates habitat conditions that provide for maximum community diversity.

Since the initial polynomials are fit to plots of mean number of individuals per habitat increment, variance around each mean is implicit within the model. Orth and Maughan (1983) suggested log transformation of the raw data to minimize these variances prior to construction of the suitability curves. In some cases, log transformation has a tendency to skew the peak of the derived suitability curve toward the lower end of the physical parameter range.

\section{RECENT APPLICATIONS OF PHABSIM FOR MACROINVERTEBRATES}

In the United States, some regulatory agencies, most notably in the state of North Carolina, have begun to include macroinvertebrate habitat evaluations as a component of minimum flow evaluations. These evaluations have been made in recommendations for release schedules for hydropower facilities as part of re-licensing efforts with the Federal Energy Regulatory Commission and for allocating water abstraction rates for various municipalities. Most often, a suite of macroinvertebrate criteria has been used in the evaluations. No species-specific curves have been employed. Instead, more generic curves for the 'EPT fauna' [Ephemeroptera, Plecoptera, and Trichoptera] (Figures 1-3) have been evaluated, since many bioassessment metrics depend upon the richness of these orders when evaluating water quality (Barbour et al., 1999). We have derived the EPT curves from a series of benthic samples (approximately 1200 individual samples with a minimum of 50 samples per location) taken over the past 10 years across a range of streams and rivers in the southeastern United States. In addition, representative criteria for benthic community diversity in high gradient or low gradient streams (the break point being arbitrarily chosen as a gradient of 0.005), as appropriate, have been concurrently evaluated. These curves have been derived from individual samples collated over the past two decades and represent some 2500 samples collected since 1974 in streams in the western, northeastern, and southeastern United States (Figures 4-6). The curves for velocity and depth were derived as the first-order differential of exponential polynomials fit to cumulative mean number of individuals (or mean sample diversity [measured as Shannon's diversity]) per increment of physical parameter, as described by Gore and Judy (1981). Substrate histograms were plotted as the mean number of individuals of that order (or mean sample diversity) per substrate category and normalized to one, as described by Bovee (1986). 


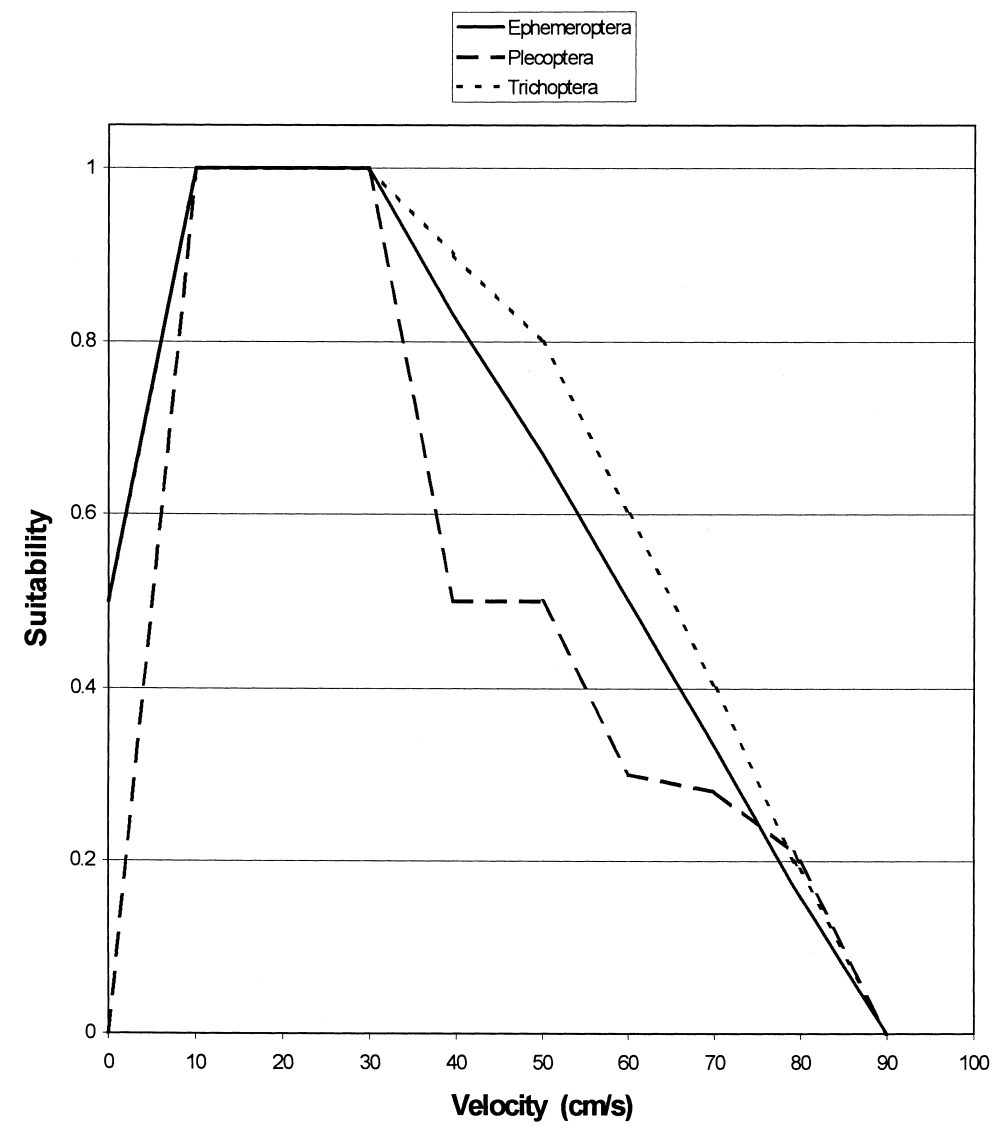

Figure 1. Velocity preference curves for EPT, based upon a pool of 1200 samples

Since we wanted to create a generic set of suitability curves, we chose to simulate a number of samples adequate to develop habitat suitability criteria. Statzner et al. $(1988,1998)$ have shown that, this value ranges between 25 and 75 samples. Thus, we chose to draw, at random, 50 samples from the pool of available samples. For each set of 50 samples, habitat suitability curves were created according to the methods of Gore and Judy (1981). This was repeated, as a Monte Carlo simulation, until the variance around the mean value for each increment of depth, velocity, and substrate remained stable. The generic curve was fit to the mean values for each increment of physical habitat condition. When this scheme was repeated more than 100 times, the curves were not significantly different from curves derived from all samples as a single pool. Thus, the curves presented (Figures 1-6) are, in effect, the mean preference curve based on all samples.

Figures 7 and 8 are from a series of evaluations of flow releases from Queens Creek in North Carolina. The recommended releases are based upon a time-series evaluation of 49 years of record, performed once with the mottled sculpin (Cottus bairdi), as a representative of the riffle fauna, and several other fish species and performed, again, with macroinvertebrate community diversity (highgradient stream) and the same suite of fish species. With the exception of those times of the month when critical habitat conditions are required for the spawning of rainbow trout (Oncorhynchus mykiss), the true bottleneck is represented by adequate flows to maintain benthic diversity. That is, when using the mottled sculpin, alone, adequate habitat for macroinvertebrates is underestimated by between 5 and $15 \%$. These results underscore the need to include macroinvertebrate community structure as a component of instream analysis in order to avoid the potential of providing inadequate habitat for secondary producers in the stream ecosystem. 


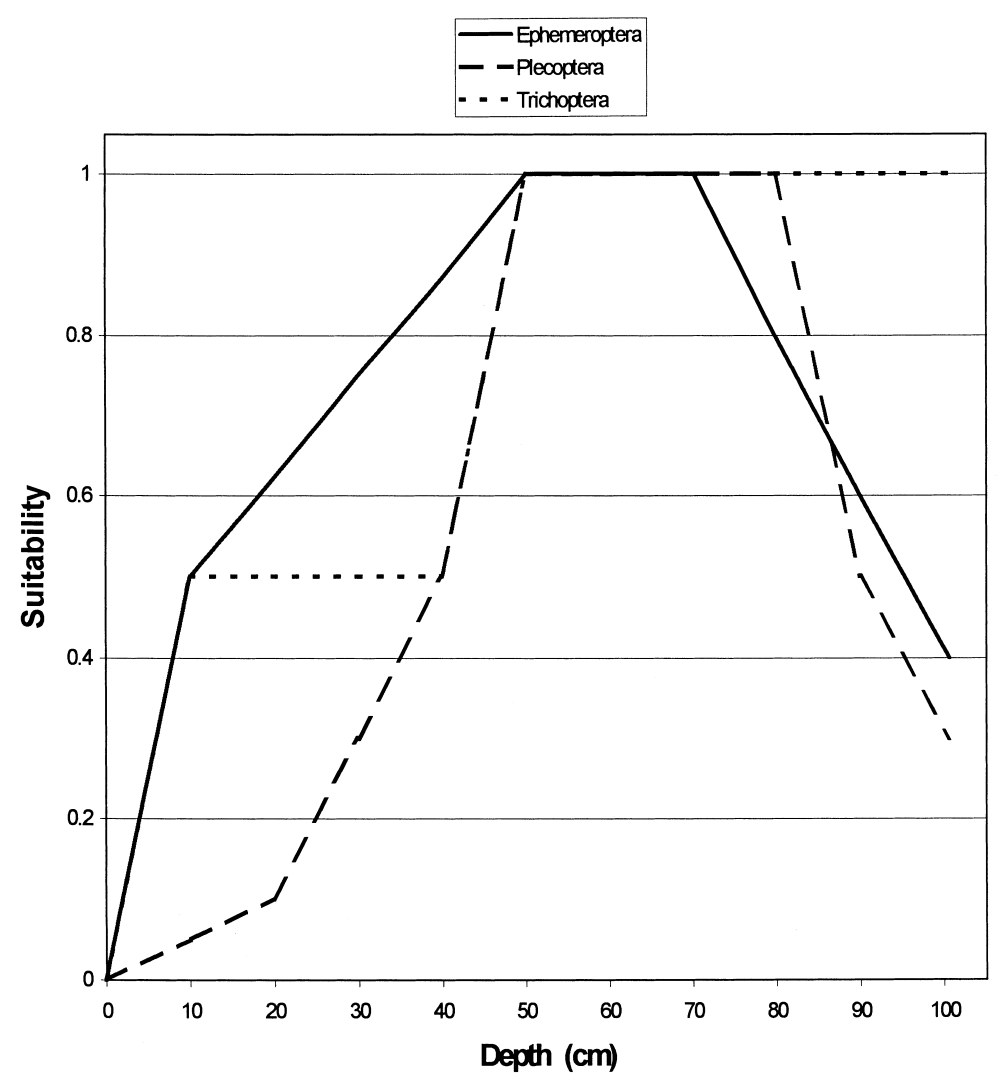

Figure 2. Depth preference curves for EPT, based upon a pool of 1200 samples

As discussed earlier in this paper, there are concerns about applying IFIM to assess the effect of flow modifications on southeastern streams of the United States, because of the high richness of fish species and limited knowledge of habitat requirements. Bowen et al. (1998) investigated the use of generalized habitat metrics, rather than species specific, as one potential approach to this dilemma. Parameters for five key habitat types were selected and IFIM site models were developed at seven locations along the Tallapoosa River in Alabama. Stream flow records for this river encompass both unregulated 'natural' flows and regulated flows following dam construction. Fish assemblage data for Cyprinidae, Centrarchidae, Catostomidae, and Percidae were also collected. Statistical analysis found correlations between the abundance of different fish groups and the median availability, as well as persistence, of each of the five habitat types. Adaptations of this approach are also planned for hydropower re-licensing studies at several locations in western North Carolina.

The use of generalized habitat criteria to augment species specific analysis is a promising development in the application of IFIM to stream management. It reduces the reliance on site and/or species specific habitat preferences that may include flawed assumptions. The analysis of persistence (in hours) and availability of key habitat conditions may also make this approach especially useful in evaluating the effects of rapidly fluctuating flows downstream of peaking hydroelectric projects. The application of the approach described by Bowen et al. (1998) could also be explored for its applicability to benthic macroinvertebrates. In fact, employing the low gradient or high gradient benthic community diversity suitability curves we have developed may approximate the use of generalized habitat metrics. Bowen et al. (1998) focused on spring and summer months as those critical for fish spawning. Benthos should be evaluated over the entire year because of their general lack of mobility, compared with fish. 

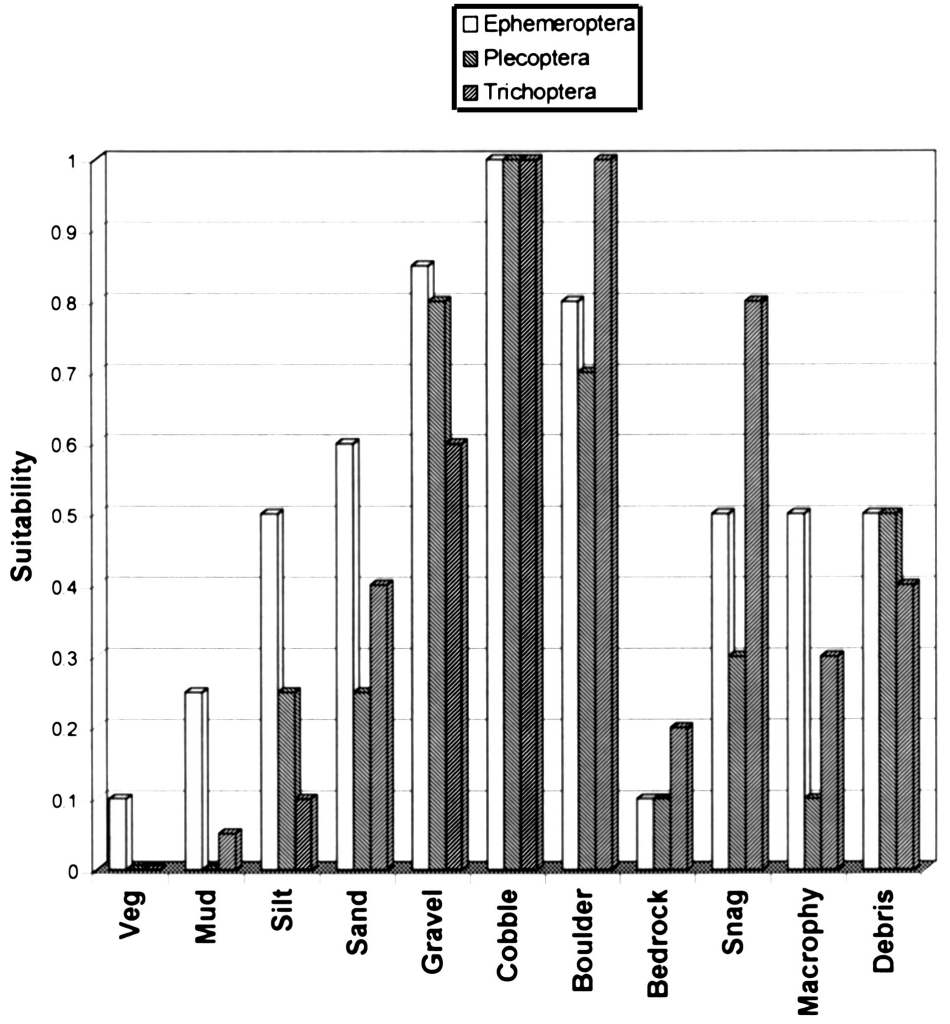

Figure 3. Substrate preferences for EPT, based a pool of 1200 samples

Another factor receiving increased attention in stream flow management is the potential for stream flow changes to alter substrate and channel morphology. A great deal of attention has been focused on minimum flows, but the elimination of occasional high flow events to flush accumulated sediment and maintain suitable substrate conditions can have long-term adverse consequences for habitat. This is especially true for benthic organisms. Richter et al. (1996) have developed a technique to assess this impact referred to as IHA - Indicators of Hydrologic Alteration.

The use of species specific IFIM analysis remains a useful and widely accepted approach to making stream flow management decisions. However, it can be greatly augmented by including benthic macroinvertebrate species, generalized habitat metrics, and indicators of hydrologic alteration to examine the full range of species, habitat conditions, and flow events. The application of generic curves does have advantages and limitations. The application of generic curves is certainly more cost-effective, especially when it is necessary to make a rapid decision on regulated river issues, and offers stream managers the chance to compare decisions and predictions across catchments and regions. However, these curves must be tempered with best professional judgement and, at times, altered (through a Delphi approach; Bovee, 1986) to fit known hydrological and physical conditions. When mussel species are involved, it cannot be demonstrated that the generic macroinvertebrate curves will adequately protect mussel species. Although Milhous (1991) has used HABEF, a subroutine in PHABSIM, to assess habitat availability for organisms with limited mobility, we suggest that the initial development of the suitability criteria remains problematic. Nevertheless, for most applications, where budgets limit the ability to gather field data and generate onsite curves, the generic curves appear to be the next best approximation of changes in habitat for benthos as a result of changing flow regimes. Since they represent a summary of preferences observed at many different sites, for comparative purposes, they may be more useful than site-specific criteria. 


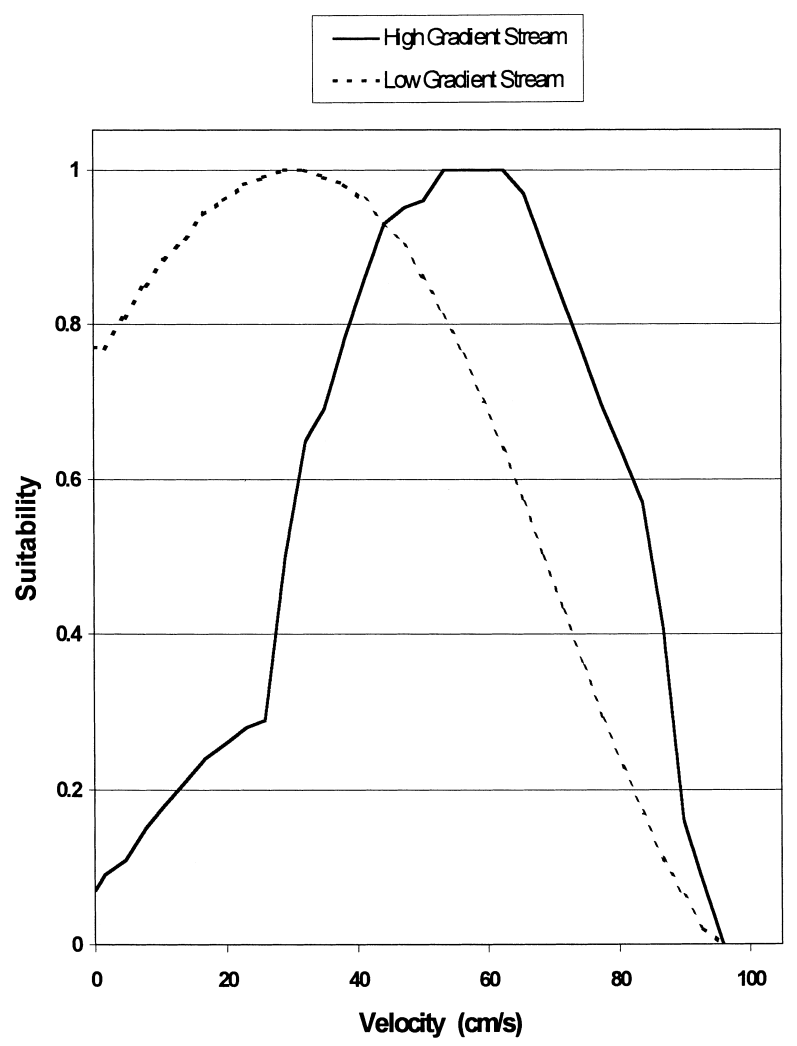

Figure 4. Velocity preferences for Macroinvertebrate Community Diversity in wadeable streams of different gradients, based upon a pool of 2500 samples

Although not a primary use of PHABSIM, the model is sufficiently robust to also allow application of the model in the evaluation of physical restoration of disturbed stream ecosystems. Gore (1985) suggested that such models might be used to evaluate the placement of structures in unregulated streams. More recently a number of attempts have been made to evaluate restoration efforts using PHABSIM. Subroutines within PHABSIM can be used to evaluate restoration design by changing cross-sectional information (channel geometry, substrate, velocities, etc.) to mimic proposed changes caused by placement of restoration structures. Wegner (1980) used this approach to evaluate the impact of excavation of pools, placement of weirs, and boulders on the Uinta River, but was unable to verify the results. Shuler and Nehring (1993) demonstrated that brown trout (Salmo trutta) habitat availability (as weighted usable area, WUA) and trout density were positively correlated over 3 years of study of restoration structures on the Rio Grande River. In these and other cases, the primary restoration effort has been focused upon recreating suitable target fish habitat.

The focus of within-channel restoration is the placement and construction of instream habitat structures to enhance the capture of organic detritus, promote the growth of periphyton or biofilm, as well as, improving the rate of colonization by macroinvertebrate and fish species (Gore, 1985). Structural design is based upon the assumption that these habitat requirements can be controlled through design of structures that produce preferred physical and chemical conditions as related to flow conditions. When emplacing structures that alter velocity, depth, and substrate composition, restoration scientists are assuming that hydraulic conditions are one of the primary templates that govern the distribution of lotic organisms (Brookes et al., 1996). For benthic macroinvertebrates, substrate composition is the most easily manipulated habitat characteristic. The most common structures for fish habitat enhancement have been current deflectors, overpour structures (dams and weirs), bank cover, and boulder placements. These 


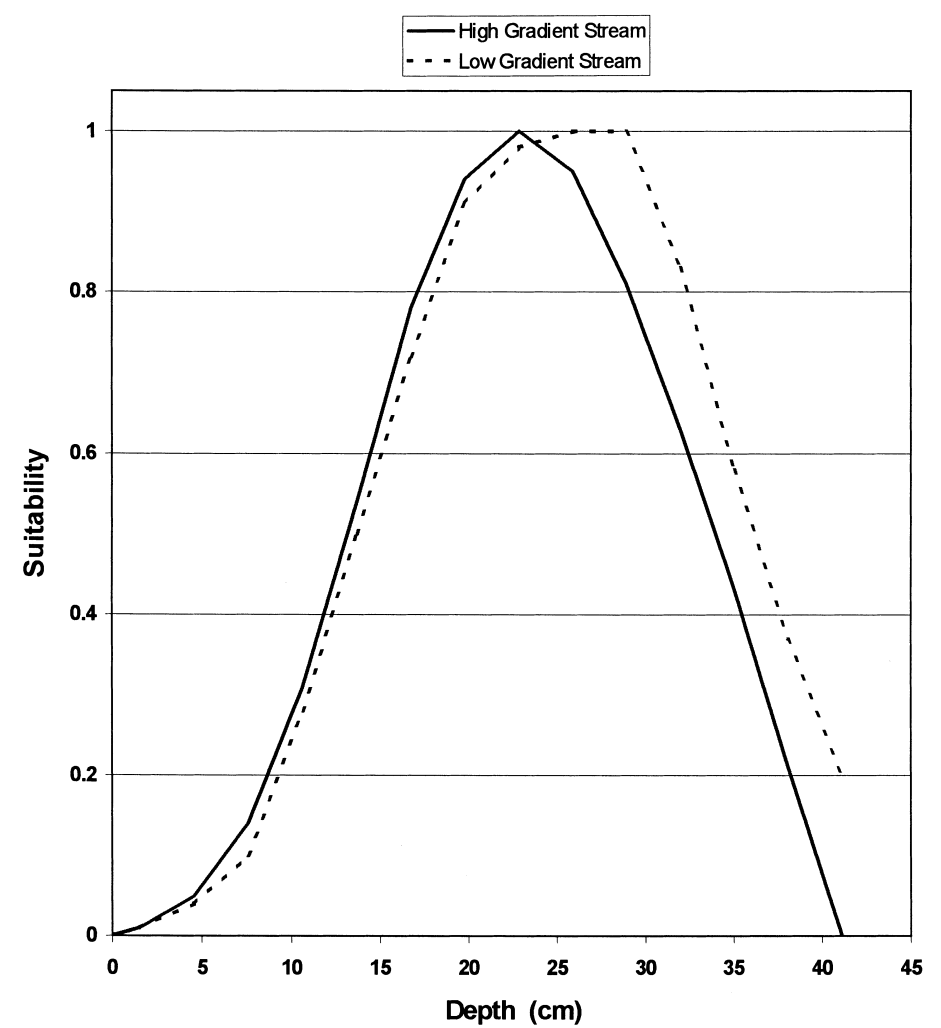

Figure 5. Depth preferences for Macroinvertebrate Community Diversity in wadeable streams of different gradients, based upon a pool of 2500 samples

instream structures also modify local hydraulic conditions to present preferred habitat to benthic invertebrates. PHABSIM has been used to evaluate stream enhancement activities with an emphasis on macroinvertebrate restoration. The placement of a series of three-log weirs on Brushy Branch, a second order stream in Tennessee, demonstrated that benthic macroinvertebrate habitat can be dramatically increased at low flows (up to five times higher) after placement of structures which improve hydraulic conditions to sustain maximum diversity of the benthic community (Gore and Hamilton, 1996). Just as in the case of predictions based upon numbers of individuals of a species, we assume that an increase in the quality of a habitat cell will result in an increase in diversity in that cell. It remains difficult to directly predict that response to increase in habitat quality. However, in a separate study, Gore et al. (1998) demonstrated that artificial riffles placed in Holly Fork, a tributary of the West Sandy River, in west Tennessee, enhanced macroinvertebrate diversity. That is, macroinvertebrate diversity increased with increases in habitat quality in each cell examined over a range of discharges. Indeed, PHABSIM was able to successfully predict the location of best habitat cells across the riffle at those discharges. The location of the optimal habitat changed from the head to the toe and back to the head of the riffle as discharge increased. Hydraulic habitat models, then, especially PHABSIM, can be a useful tool to evaluate the benefit of certain restoration activities. In low-order streams, evaluation of benthic communities may well be the best indicator of restoration success.

\section{COMPLEX HYDRAULIC MODELS}

Turbulence, shear stress, and other near-bed phenomena are the result of the simultaneous interaction of velocity, depth, and substrate. Thus, suitability criteria have been criticized for the lack of this 


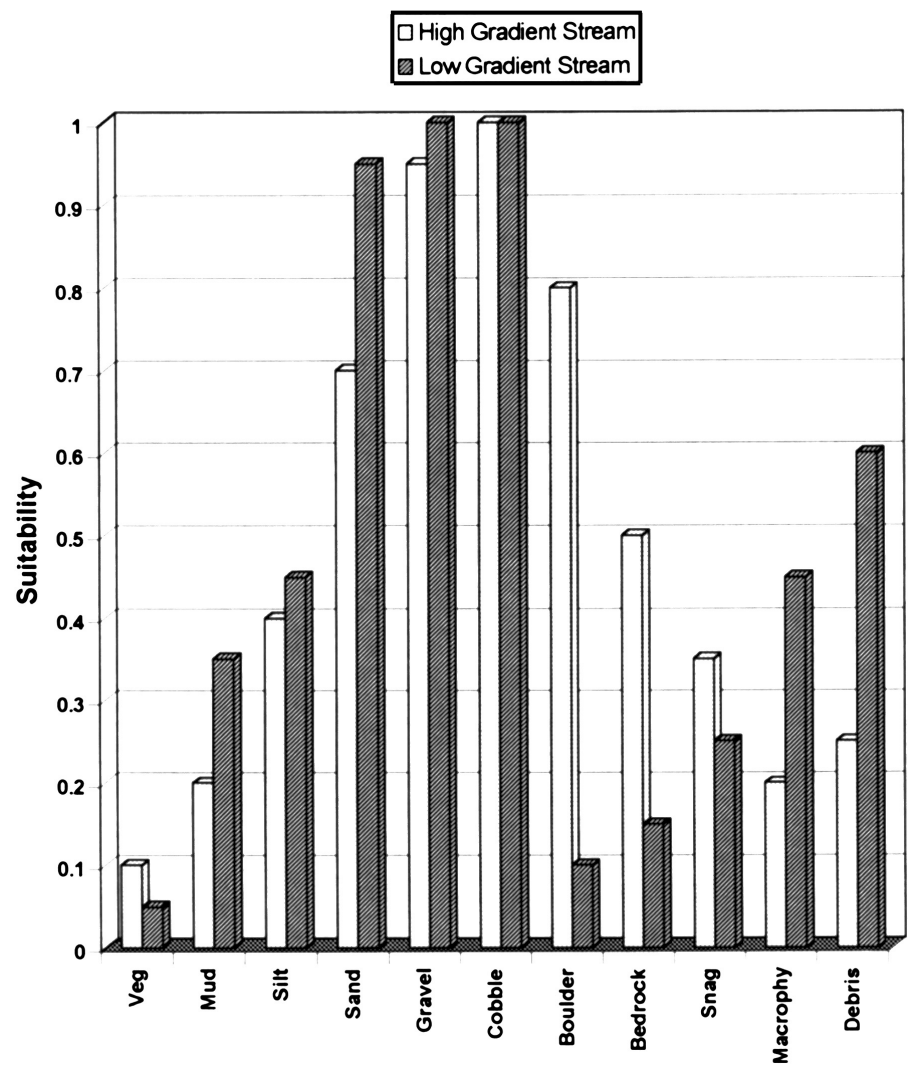

Figure 6. Substrate/Cover preferences for Macroinvertebrate Community Diversity in wadeable streams of different gradients, based upon a pool of 2500 samples

interrelationship in production of habitat information (Mathur et al., 1985). Gore and Judy (1981) presented an alternate model that included joint velocity and depth terms in an exponential polynomial equation. A multiple regression of frequency distributions of velocity and depth provided the constants for the equation. The result is a response surface depicting the changes in preference as a function of changes in simultaneous change in depth and velocity. Morin et al. (1986) found that the exponential polynomial curves had the effect of minimizing variances and were more accurate density predictors than the standard IFIM suitability curves and their log-transformed modifications.

Statzner (1987, 1988) and Statzner and Holm (1982, 1989) have conducted extensive tests of the hydrodynamics of benthic macroinvertebrates and have produced a series of models of complex hydraulic conditions that accurately predict the distribution and density of aquatic macroinvertebrates. Although these models are, undoubtedly, more accurate, in ecological terms, the employment of these complex hydraulic models requires extensive modification of the habitat packages within PHABSIM to accommodate the suitability curves. HABTAT, for example, does contain options to examine shear stress and other near-bed phenomena, but remains based upon velocity, depth, and substrate curves produced independently.

At first, this may sound as a criticism of the currently employed habitat suitability curves and a call for the renewed development of macroinvertebrate habitat models. However, in a small number of tests of these models, PHABSIM appears to be doing a more than adequate job of prediction and as a management tool. Gore et al. (1998) found that composite suitability curves were able to predict community diversity of benthic macroinvertebrates in areas downstream of restoration structures on low-order streams. Similarly, Statzner et al. (1998), in a direct comparison of complex hydraulic models 


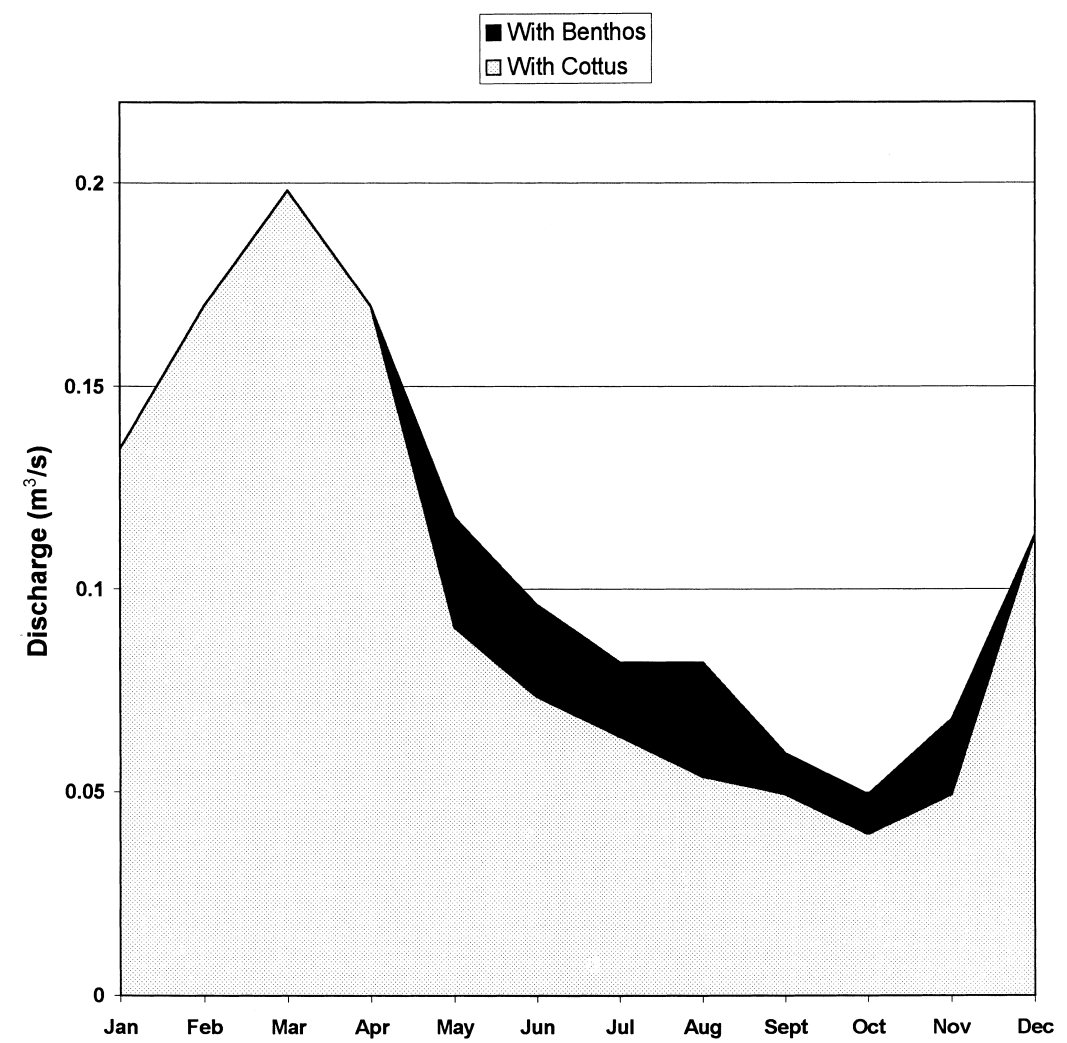

Figure 7. A comparison of recommended monthly minimum releases on Queens Creek, North Carolina, with a $20 \%$ reduction in habitat allowed. Based on predictions using only a riffle-feeding benthic fish (Cottus bairdi) and including benthic macroinvertebrate diversity. This results in a $4.3 \%$ annual volumetric increase to protect benthos

and the simpler habitat suitability curves used in IFIM, found that the simple habitat suitability curves did a better job of predicting densities, with smaller sample sizes required, when attempting to predict sample density of over 250 samples of Aphelocheirus aestivalis from rivers of central Germany.

\section{MUSSEL FAUNA - NEW APPROACHES}

Although many factors have contributed to the extinction of numerous freshwater mussel species and populations, and should be considered in mussel conservation (Layzer et al., 1993; Chesney and Oliver, 1998; Killeen et al., 1998; Hughes and Parmalee, 1999; Cosgrove et al., 2000), we restrict our discussion here to the influence of hydraulics on mussel populations. Freshwater mussels differ from most other macroinvertebrates in several ways that can affect assessment of their instream flow requirements (Table I). In particular, the limited mobility of mussels mandates that a different approach be used to define their flow requirements. Layzer and Madison (1995) argued that suitability indices developed for one discharge were of little use in predicting mussel habitat at other discharges. Spatially, mussel habitats are often well defined and restricted to patches (mussel beds). Barring catastrophic floods that reshape the stream channel, the locations of these beds remain constant among years and over a wide range of discharge. Mussels cannot move quickly enough to follow the changing location of suitable habitat as discharge varies. Figure 9 is a hypothetical example of a PHABSIM prediction of suitable habitat based on typical habitat suitability indices developed at base flow (Q3). As flow decreases (Q2, Q1), there is decreasing overlap between the predicted location of suitable habitat and the actual location of the mussel bed. Superficial examination of weighted usable area would seemingly show little change in the amount of 


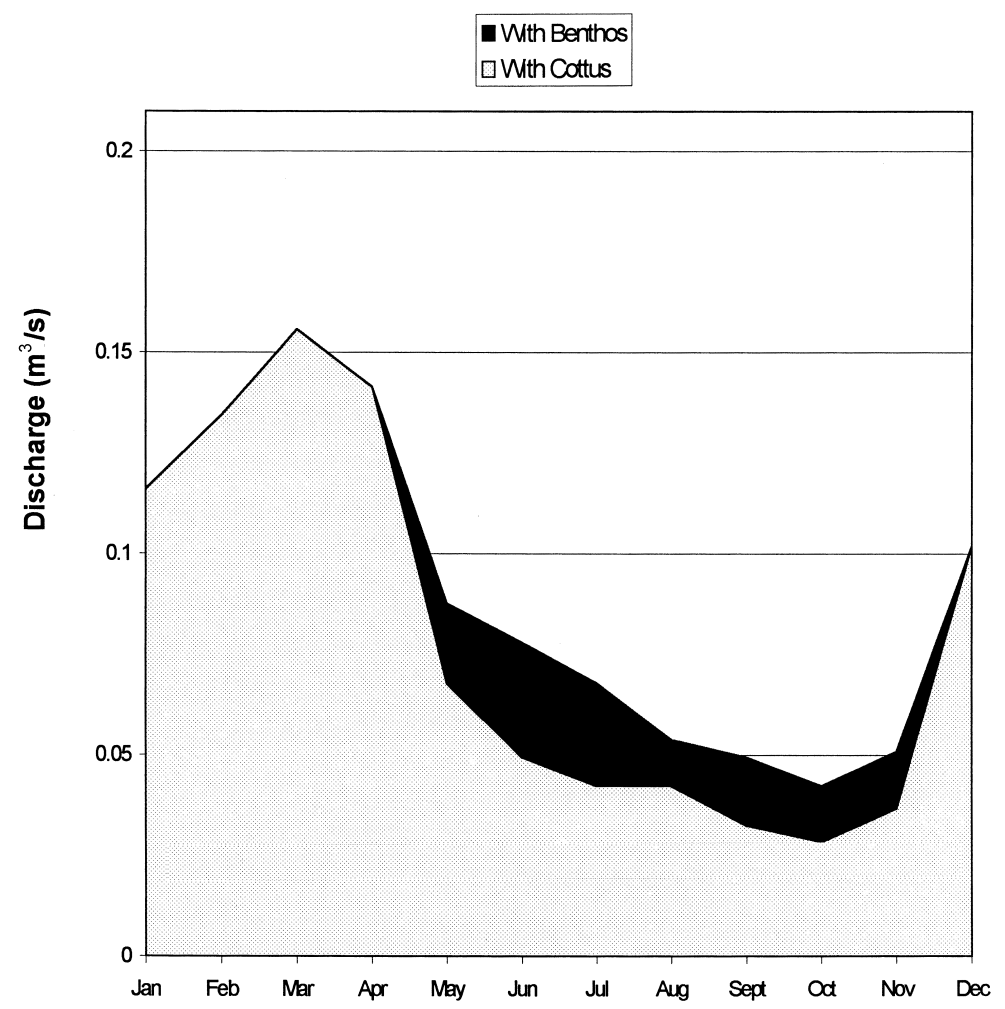

Figure 8. A comparison of recommended monthly minimum releases on Queens Creek, North Carolina, with a $35 \%$ reduction in habitat allowed. Based on predictions using only a riffle-feeding benthic fish (Cottus bairdi) and including benthic macroinvertebrate diversity. This results in a $13.9 \%$ annual volumetric increase to protect benthos

Table I. Characteristics of freshwater mussels and most other macroinvertebrates

\begin{tabular}{lll}
\hline Characteristic & Most mussels & Most macroinvertebrates \\
\hline Life-span & Long ( >30 years) & Short ( <3 years) \\
Mobility & Limited & Moderate \\
Recruitment & Irregular & Regular \\
Recolonization & Slow & Rapid \\
Tolerance of adults to flow extremes & High & Low \\
\hline
\end{tabular}

habitat available as discharge decreased; however, because the mussel bed was not in the predicted area of suitable habitat, the decrease would be more severe than predicted.

Defining the physical environment mussels occupy in lotic systems has been the subject of much recent research (Holland-Bartels, 1990; Strayer and Ralley, 1993; Layzer and Madison, 1995; Hastie et al., 2000). Despite these efforts, our understanding of preferred habitats and instream flow requirements of mussels is in its infancy. Layzer and Madison (1995) suggested that shear stress was a major factor in determining where juvenile mussels settled, and consequently, determines if recruitment to existing beds would occur. Strayer (1999) demonstrated that mussel beds were located in high-flow refugia. However, mussels are not uniformly distributed within a bed. Similarly, shear velocity varies on a small spatial scale within mussel beds and is negatively correlated with mussel density (Hardison and Layzer, 2001).

Although the use of a community model is suitable for determining flow requirements for most macroinvertebrates, such an approach is not appropriate for freshwater mussels. Available evidence indicates that instream flow needs are not necessarily the same for all species (Hardison and Layzer, 
MUSSEL HABITAT AT 3 DISCHARGES
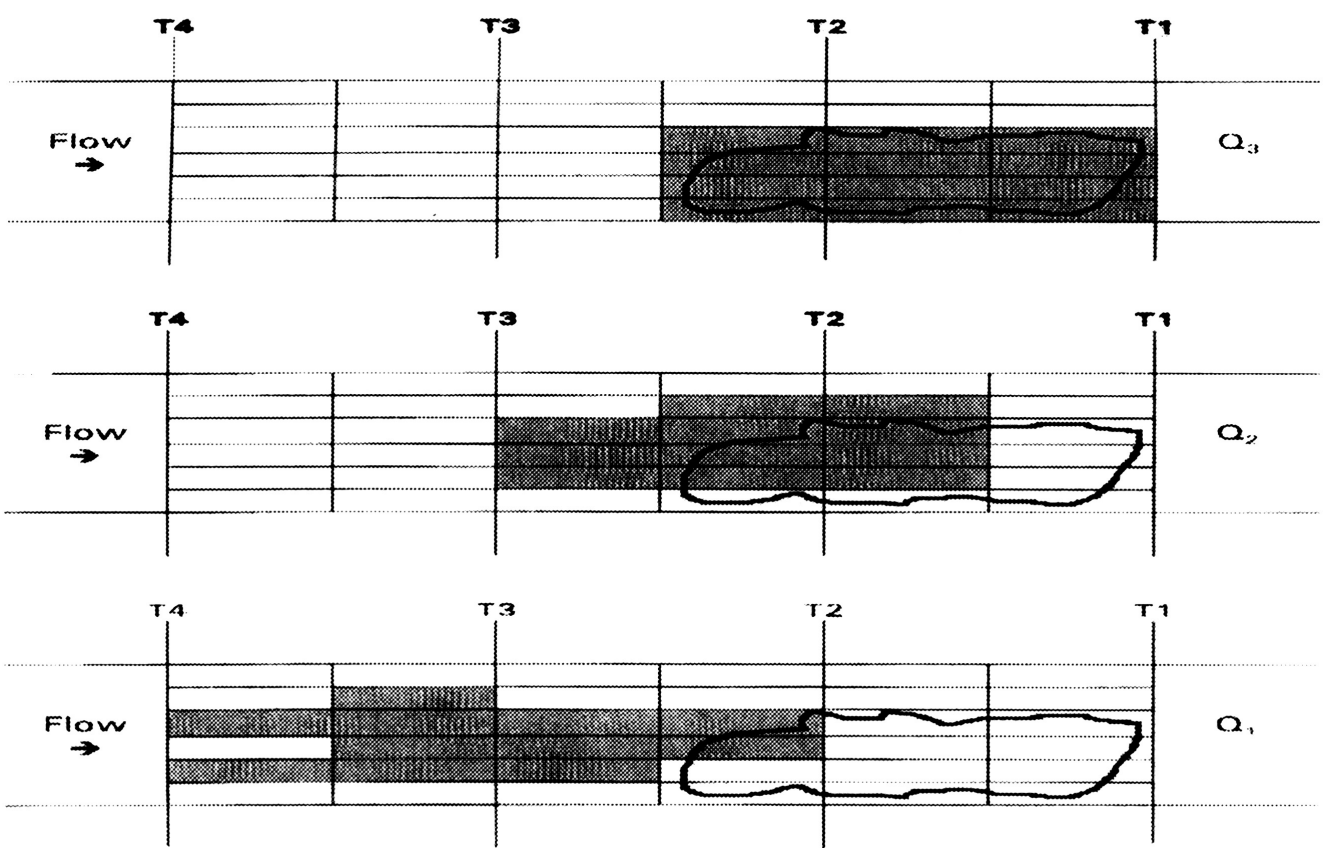

Figure 9. Hypothetical distribution of optimal habitat conditions (WUA) as discharge changes (Q1-Q3) across the stream reach; however, the mussel bed remains within the segment represented by transects 1 and 2 (T1, T2)

2001). Moreover, temporal variability in flows is believed to be important in maintaining diverse assemblages. Although the instream flow requirements for many macroinvertebrates has been the subject of research for over 20 years, specific attempts to delineate such needs for freshwater mussels is largely restricted to the past 5 years. Furthermore, actually providing a flow regime for mussel populations largely remains an untested management option. Layzer and Madison (1995) provided some interim recommendations for instream flow requirements of mussels, including minimum depths and velocities; however, they cautioned that these minima may be suitable only for temporary maintenance of mussel populations.

Many species of mussels live over 30 years, and in regulated and unregulated streams, successful recruitment is often highly variable among years. At least some of this variability is linked to variations in annual hydrographs. Recruitment for some species seems to be greatest at below average discharges, while other species may require a more normal flow rate for successful recruitment. Ultimately, recruitment is the sole measure of how successful any flow regime is for providing conservation flows for freshwater mussels. Therefore, we suggest a two-stage process for determining conservation flows for mussels. Initially, historic flow regimes should be linked to patterns in mussel recruitment. Following institution of a conservation flow regime, the level of recruitment should be monitored to insure that flows are suitable for maintaining or increasing existing population levels. To maintain diverse mussel assemblages, annual hydrographs may have to vary seasonally and annually to provide optimal flows for different groups of species. Although this recommended methodology does not lend itself readily to an IFIM analysis, PHABSIM should be used to assess habitat of host fishes, and flows necessary for instream movement. Moreover, PHABSIM predictions can be used to insure that suitable habitat for host fishes occurs in the immediate vicinity of mussel beds to increase the likelihood of successful glochidial attachment. We recognize that this proposed methodology will require much time and expense; however, it is justified to insure the survival of many mussel species on the brink of extinction. 


\section{CONCLUSION}

Despite criticisms of PHABSIM and habitat suitability models for their lack of ecological sincerity, the IFIM technique provides a useful tool to stream managers to ascertain which flows will substantively alter habitat availability. The greatest need is the inclusion of macroinvertebrate suitability curves in the assessment of lotic ecosystem integrity under regulated flows. Differences in predicted optimal and minimum flow criteria do indicate that managing for a few target invertebrate species may result in the loss of habitat for other non-target species while flows that are appropriate for functional feeding group targets or for highest community diversity provide a greater proportion of habitat for benthic species. Maintaining a high community diversity among benthic macroinvertebrates or the appropriate proportion of functional feeding groups will likely insure a diversity of hydraulic conditions within the stream reach in question and it is a relatively simple procedure to produce suitability criteria for highest levels of benthic community diversity.

The second issue that faces the continued development of instream flow models applies to analysis of all trophic levels in stream ecosystems. That is, where should our efforts be focused in the future? Currently, we do not understand if or why more complex hydraulic models improve the predictive power of PHABSIM. The initial results of Statzner et al. $(1988,1998)$ are equivocal. Intuitively, it would appear that simulations of near-bed conditions should predict benthic macroinvertebrate 'responses' with greater accuracy and precision; however, this has not been the case. At the same time, parallel efforts are focusing upon more complex two- and three-dimensional models of hydraulic conditions (LeClerc et al., 1995; Waddle, 1998) and more simple models combining multivariate and statistical models of habitat suitability (Lamouroux et al., 1996). Should we focus upon improvement of biological models, hydrological models or both? Although we cannot suggest that any single approach is best, it must be the responsibility of the developers of new models to demonstrate that the application of the new models will significantly alter the management decisions that are being made using the more simple models being currently applied.

\section{ACKNOWLEDGEMENTS}

This paper was presented as part of a special symposium on instream flow issues at the Eighth International Symposium on Regulated Streams, held in Toulouse, France. The authors would like to thank Dr Hervé Capra, CEMAGREF, and an anonymous referee for their helpful comments and suggestions to improve this manuscript.

\section{REFERENCES}

Barbour MT, Gerritsen J, Snyder BD, Stribling JB. 1999. Rapid Bioassessment Protocols for Use in Streams and Wadeable Rivers: Periphyton, Benthic Macroinvertebrates and Fish. EPA 841-B-99-002 (2nd edn). US Environmental Protection Agency, Office of Water: Washington, DC.

Bovee KD. 1985. Evaluation of the effects of hydropeaking on aquatic macroinvertebrates using PHABSIM. In Proceedings of the Symposium on Small Hydropower and Fisheries, Olson FW, White RG, Hamre RH (eds). American Fisheries Society: Denver, CO; 236-242.

Bovee KD. 1986. Development and evaluation of habitat suitability criteria for use in the instream flow incremental methodology. Instream Flow Information Paper No. 21, Biological Report 86(7), US Fish and Wildlife Service, Washington, DC.

Bovee KD, Lamb BL, Bartholow JM, Stalnaker CB, Taylor J, Henriksen J. 1998. Stream habitat analysis using the Instream Flow Incremental Methodology. Information and Technology Report USGS/BRD-1998-0004. US Geological Survey, Biological Research Division, Washington, DC.

Bowen ZH, Freeman MC, Bovee KD. 1998. Evaluation of generalized habitat criteria for assessing impacts of altered flow regimes on warmwater fishes. Transactions of the American Fisheries Society 127: 455-468.

Brookes A, Knight SS, Shields FD Jr. 1996. Habitat enhancement. In River Channel Restoration. Guiding Principles for Sustainable Projects, Brookes A, Shields FD Jr (eds). Wiley: New York; 103-126.

Brusven MA, Prather KV. 1974. Influence of stream sediments on distribution of macrobenthos. Journal of the Entomological Society of British Columbia 71: 24-32. 
Brusven MA, Rose ST. 1981. Influence of substrate composition and suspended sediment on insect predation by the torrent sculpin, Cottus rhotheus. Canadian Journal of Fisheries and Aquatic Sciences 38: 1444-1448.

Chesney HCG, Oliver PG. 1998. Conservation issues for the Margaratiferidae in the British Isles and western Europe. Journal of Conchology, Special Publication 2: 231-242.

Cosgrove PJ, Young MR, Hastie LC, Gaywood M, Boon PJ. 2000. The status of the freshwater pearl mussel Margaritifera margaritifera Linn. in Scotland. Aquatic Conservation: Marine and Freshwater Ecosystems 10: 197-208.

Cummins KW. 1996. Invertebrates. In River Biota. Diversity and Dynamics, Petts G, Calow P (eds). Blackwell Science: Oxford; 75-91.

Freeman MC. 1998. Developing and using habitat suitability criteria for fish guilds: experiences from the southeastern United States. In Hydroecological Modelling. Research, Practice, Legislation and Decision-Making, Blazková S, Stalnaker C, Novický O (eds). T.G. Masaryk Water Research Institute: Prague; 52-54.

Gore JA. 1977. Reservoir manipulations and benthic macroinvertebrates in a prairie river. Hydrobiologia 55: 113-123.

Gore JA. 1978. A technique for predicting the in-stream flow requirements of benthic macroinvertebrates. Freshwater Biology 8: $141-151$.

Gore JA. 1985. Mechanisms of colonization and habitat enhancement for benthic macroinvertebrates in restored river channels. In The Restoration of Rivers and Streams, Gore JA (ed.). Butterworths: Stoneham, MA; 81-101.

Gore JA. 1987. Development and applications of macroinvertebrate instream flow models for regulated flow management. In Regulated Streams: Advances in Ecology, Craig JF, Kemper JB (eds). Plenum Press: New York; 99-115.

Gore JA. 1989. Models for predicting benthic macroinvertebrate habitat suitability under regulated flows. In Alternatives in Regulated River Management, Gore JA, Petts GE (eds). CRC Press: Boca Raton, FL; 253-265.

Gore JA. 1996. Responses of aquatic biota to hydrological change. In River Biota. Diversity and Dynamics, Petts GE, Calow P (eds). Blackwell Science: Oxford; 209-230.

Gore JA, Crawford DJ, Addison DS. 1998. An analysis of artificial riffles and enhancement of benthic community diversity by Physical Habitat Simulation (PHABSIM) and direct observation. Regulated Rivers: Research and Management 14: 69-77.

Gore JA, Hamilton SW. 1996. Comparison of flow-related habitat evaluations downstream of low-head weirs on small and large fluvial ecosystems. Regulated Rivers: Research and Management 12: 459-469.

Gore JA, Judy RD Jr. 1981. Predictive models of benthic macroinvertebrate density for use in instream flow studies and regulated flow management. Canadian Journal of Fisheries and Aquatic Science 38: 1363-1370.

Gore JA, Milner AM. 1990. Island biogeographic theory: can it be used to predict lotic recovery rates? Environmental Management 14: $737-753$.

Hardison BS, Layzer JB. 2001. Relations between complex hydraulics and the localized distribution of mussels in three regulated rivers. Regulated Rivers: Research and Management 17: 77-84.

Harvey MD, Watson CC. 1986. Fluvial processes and morphological thresholds in incised channel restoration. Water Research Bulletin 22: 359-368.

Hastie LC, Boon PJ, Young MR. 2000. Physical microhabitat requirements of freshwater pearl mussels, Margaritifera margaritifera (L.). Hydrobiologia 429: 59-71.

Holland-Bartels LE. 1990. Physical factors and their influence on the mussel fauna of a main channel border habitat of the upper Mississippi River. Journal of the North American Benthological Society 9: 327-335.

Hughes MN, Parmalee PW. 1999. Prehistoric and modern freshwater mussel (Mollusca: Bivalvia,: Unionoidea) faunas of the Tennessee River: Alabama, Kentucky, and Tennessee. Regulated Rivers: Research and Management 15: 25-42.

Hutchinson GE. 1959. Homage to Santa Rosalia or why are there so many kinds of animals? American Naturalist 93: $145-159$.

Hynes HBN. 1970. The Ecology of Running Waters. University of Toronto Press: Toronto.

Killeen IJ, Oliver PG, Fowles AP. 1998. The loss of a freshwater pearl mussel M. margaritifera population in NW Wales. Journal of Conchology, Special Publication 2: 245-250.

Lamouroux N, Capra H, Pouilly M. 1996. A perspective to predict habitat suitability of lotic fish: linking statistical hydraulic with multivariate habitat use models. In Proceedings of the 2nd International Symposium on Habitat Hydraulics, Leclerc M, Capra H, Valentin S, Boudreault A, Côté Y (eds). INRS-EAU: Quebec; B95-B106.

Layzer JB, Gordon ME, Anderson RM. 1993. Mussels: the forgotten fauna of regulated rivers. A case study of the Caney Fork River. Regulated Rivers: Research and Management 8: 63-71.

Layzer JB, Madison LM. 1995. Microhabitat use by freshwater mussels and recommendations for determining their instream flow needs. Regulated Rivers: Research and Management 10: 329-345.

LeClerc M, Boudreault A, Bechara JA, Corfa G. 1995. Two-dimensional hydrodynamic modeling: a neglected tool in the instream flow incremental methodology. Transactions of the American Fisheries Society 124: 645-662.

Leonard PM, Orth DJ. 1988. Use of habitat guilds to determine instream flow requirements. American Journal of Fisheries Management 8: 399-409.

Mathur D, Bason WA, Purdy EJ Jr, Silver CA. 1985. A critique of the Instream Flow Incremental Methodology. Canadian Journal of Fisheries and Aquatic Science 42: 825-831.

Milhous RT. 1991. Instream flow needs below peaking hydroelectric projects. In Proceedings of the International Conference on Hydropower, Darling DD (ed.). American Society of Civil Engineers: New York; 163-172.

Milhous RT, Wegner DL, Waddle T. 1984. User's Guide to the Physical Habitat Simulation System. US Fish and Wildlife Service, FWS/OBS 81/43: Washington, DC. 
Morin A, Harper P-P, Peters RH. 1986. Microhabitat-preference curves of blackfly larvae (Diptera: Simuliidae): a comparison of three estimation methods. Canadian Journal of Fisheries and Aquatic Sciences 43: 1235-1241.

Mundie JH. 1974. Optimization of the salmonid nursery stream. Journal of the Fisheries Research Board Canada 31: $1827-1837$.

Nowell ARM, Jumars PA. 1984. Flow environments of aquatic. Annual Review of Ecology and Systematics 15: $303-328$.

Orth DJ, Maughan OE. 1983. Microhabitat preferences of benthic fauna in a woodland stream. Hydrobiologia 106: $157-168$.

Pearson DC. 2000. Special issue: Developing multiple-species conservation reserves and habitat conservation plans-Preface. Environmental Management 26(Suppl. 1): S1.

Redak RA. 2000. Arthropods and multispecies habitat conservation plans: Are we missing something? Environmental Management 26(Suppl. 1): S97-S107.

Richter BD, Baumgartner JV, Braun DP. 1996. A method for assessing hydrologic alteration within ecosystems. Conservation Biology 10: 1163-1174.

Shuler SW, Nehring RB. 1993. Using the Physical Habitat Simulation model to evaluate a stream habitat enhancement project. Rivers 4: 175-193.

Stalnaker C, Lamb BL, Henriksen J, Bovee K, Bartholow J. 1995. The instream flow incremental methodology. A primer for IFIM. Biological Report 29, National Biology Service, US Fish and Wildlife Service, Washington, DC.

Statzner B. 1987. Characteristics of lotic ecosystems and consequences for future research direction. In Potentials and Limitations of Ecosystem Analysis. Ecological Studies, vol. 61, Schulze E-D, Zwölfer H (eds). Springer-Verlag: Berlin; 365-390.

Statzner B. 1988. Growth and Reynolds number of lotic macroinvertebrates: a problem for adaptation of shape to drag. Oikos 51: 84-87.

Statzner B, Gore JA, Resh VH. 1988. Hydraulic stream ecology: observed patterns and potential applications. Journal of the North American Benthological Society 7: 307-360.

Statzner B, Gore JA, Resh VH. 1998. Monte Carlo simulation of benthic macroinvertebrate populations: estimates using random stratified and gradient sampling. Journal of the North American Benthological Society 17: 324-337.

Statzner B, Holm TF. 1982. Morphological adaptations of benthic invertebrates to stream flow — an old question studied by means of a new technique (Laser Doppler Anemometry). Oecologia 53: 290-292.

Statzner B, Holm TF. 1989. Morphological adaptation of shape to flow: microcurrents around lotic macroinvertebrates with known Reynolds numbers at quasi-natural flow conditions. Oecologia 78: 145-157.

Strayer D. 1999. Effects of alien species on freshwater mollusks in North America. Journal of the North American Benthological Society 18: 74-98.

Strayer DL, Ralley J. 1993. Microhabitat use by an assemblage of stream-dwelling unionaceans (Bivalvia), including two rare species of Alasmidonta. Journal of the North American Benthological Society 12: 247-258.

Surber EW. 1937. Rainbow trout and bottom fauna production in one mile of stream. Transactions of the American Fisheries Society 66: $193-202$.

Waddle T. 1998. Development of 2-dimensional habitat models. In Hydroecological Modelling, Blazková Š, Stalnaker C, Novický O (eds). T.G. Masaryk Water Research Institute and USGS, Biological Research Division: Prague and Fort Collins, CO; $19-22$.

Waters TF, Knapp RJ. 1961. An improved stream bottom fauna sampler. Transactions of the American Fisheries Society 90: $225-226$.

Wegner DL. 1980. Evaluation and simulation of aquatic habitat improvements, MS Thesis, Colorado State University, Fort Collins, CO. 